\title{
Eosinophilic Ascites Due to Eosinophilic Gastroenteritis - Cytological Approach
}

\author{
Ilhami Romus*
}

\begin{abstract}
ABSTRAK
Eosinophilic ascites (EA) merupakan kasus yang sangat jarang. EA merupakan gejala yang paling jarang dari penyakit gastroenteritis eosinofilik (EGE). EA terjadi karena adanya edema dan peradangan eosinofilik dari lapisan serosa usus halus dan dapat melibatkan segmen lain pada saluran gastrointestinal. Kami melaporkan kasus seorang wanita berusia 19 tahun dengan gambaran mikroskopik sitologi cairan asites tampak eosinofil yang cukup padat dan pemeriksaan histopatologi dari biopsi lambung menunjukkan infiltrasi eosinofil. Data klinis menunjukkan adanya nyeri abdomen difus, mual, distensi abdomen, ascites sedang, dan diare. Hasil Magnetic Resonance Imaging (MRI) menunjukkan adanya penebalan dinding usus halus difus dan tidak mendeteksi keganasan primer. Hasil tes laboratorium menunjukkan eosinofilia pada pemeriksaan darah tepi, kadar IgE serum meningkat dan negatif untuk infeksi parasit. Pasien mendapatkan terapi SLE selama 1 tahun tanpa perbaikan yang nyata. Pengobatan dengan kortikosteroid menormalkan hasil tes laboratorium dan asites teratasi segera. EGE merupakan kasus yang langka dan harus diingat pada pasien dengan gejala ascites yang tidak diketahui penyebabnya.
\end{abstract}

Kata kunci: Gastroenteritis eosinofilik, asites eosinofilik, kortikosteroid.

Eosinophilic ascites (EA) is probably the most unusual and rare presentation of eosinophilic gastroenteritis (EGE) and is generally associated with the subserosal form of EGE. EGE is an uncommon disorder that is characterized by tissue and peripheral blood eosinophilia in the absence of a known cause for the latter, such as parasitic infestation, malignancy or allergy. It can present with a wide spectrum of symptoms, may affect essentially any part, and can involve any or all layers of the gastrointestinal tract. Most reported cases of EA are idiopathic, often accompanied by an atopic condition, such as asthma, or a food or medication allergy. There is no single diagnostic test or procedure that would point directly to the diagnosis and there are no strict or uniform diagnostic criteria ${ }^{1}$. We reported the rare cases of EA which diagnosis is made based on imaging, laboratory results, cytological findings and good response following treatments with steroids.

\footnotetext{
* Korespondensi email : ilhamiromus@yahoo.co.id KJF Patologi Anatomi, Fakultas Kedokteran Universitas Riau
}

\section{CASE REPORT}

Yellowish ascitic fluid from 19-year-old woman, volume $100 \mathrm{cc}$ was referred to pathological anatomic laboratory for cytological examination with clinical data was abdominal pain. While 4 fragmented gastric biopsy tissues were referred to histopathological examination with endoscopic diagnosis was Pangastritis. Cytological examination showed seluler inflammatory cells consists of neutrophil dominan, eusinophil, lymphocyte, plasma cell and macrophage. Background of this cytology preparation was clear, there were no necrotic debris or fibrilar matrics like supurativa inflammation. This feature showed sterile pus, but spesicifically there were many eosinophils infiltration and concluded as Eosinophilic Ascites. While, histological examination showed antral and fundal gastric mucosa with eosinophils infiltration, although not too much and concluded as Moderate chronic gastritis with eusinophils infiltration. 

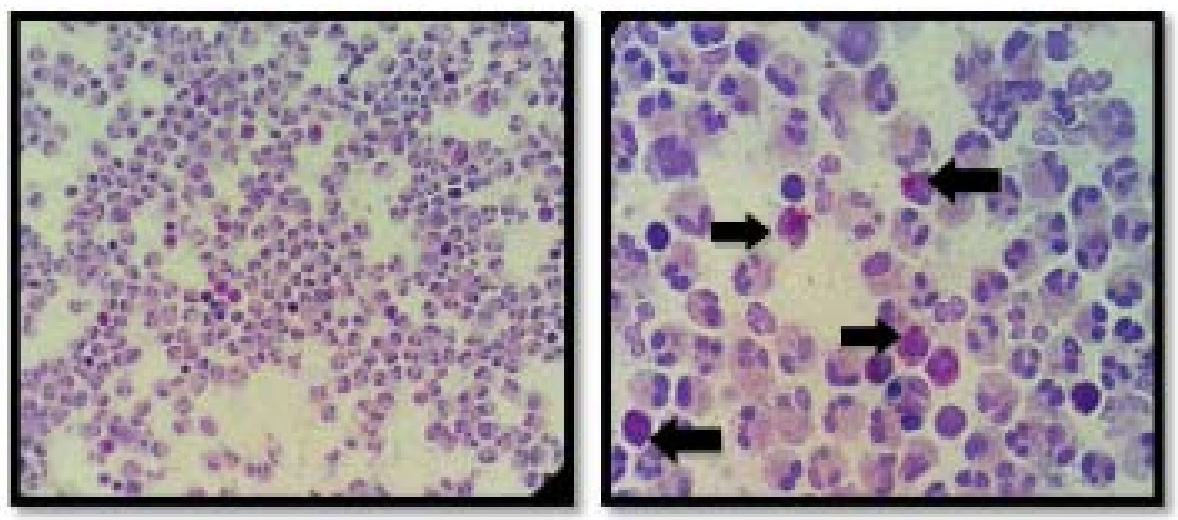

Fig 1. Eosinophils between netrophils infiltration and clear background (Giemsa 4x, $40 \mathrm{x})$

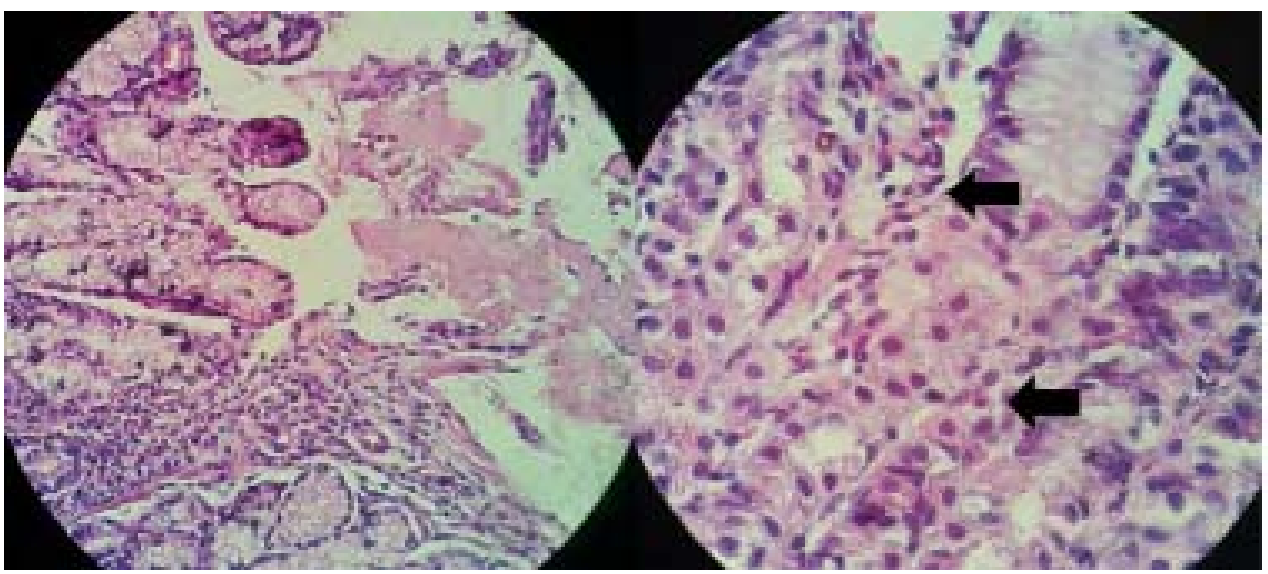

Fig 2. Mucosa and lamina propria with eosinophilic infiltrate (HE4x, 40x)

Clinical data showed this patient have been treated as Systemic Lupus Eritematosus (SLE) for 1 year without significant recovery. Now, patient with recurrent severe gastroenteritis complaints consist of abdominal pain, nausea, vomiting, and episodic diarrhea. Physical examination showed there were no fever, hemodinamic disorder, chills, respiratory symptoms, joint swelling or skin rash. There were no hepatomegali or splenomegali. There were no history of atopy, allergy, transfusion, recent travel, liver or heart disease. There were diffuse and soft abdominal tenderness and signs of ascites. Routine laboratory tests revealed a white blood cell count of $36.490 /$ ul (15,5\% neutrophils, 10,7\% lymphocytes, $2,9 \%$ monocytes and 70,9 eosinophils). Hemoglobin levels, erythrocyte sedimentation rate, electrolyte levels, coagulation test results, measures of liver and renal function, total protein count, urinary sediment and pancreatic enzyme were all in the normal range. Urinalisa and stool examination were in normal range. Blood and ascitic fluid culture were steril. IgE total slightly increase 105,20 IU/ml (normal < $100 \mathrm{IU} /$ $\mathrm{ml}$ ). Adenosin Deaminase (ADA) of ascitic fluid was negative. Upper gastrointestinal endoscopy showed hyperemia of the antral and corpus mucosa.

In the past, patient had examined for MRI showed the presence of acites, diffuse edema and thickening of small bowel wall but no sings suggesting malignancy, normal appearance of the liver and portal circulation. She had laparascopy and omentum biopsy, the result showed inflammatory reaction with eosinophil infiltration.

According to imaging, laboratory results, clinical findings and pathologic result, patient diagnosed as Eosinophilic GastroEnteritis. Patient 
have good response in clilinically and laboratory following treatment with steroids. Abdominal pain, nausea and vomiting disappear. Leukocyte number decrease significant after therapy steroid become $11.600 / \mathrm{ul}$ without eosinophilia $4,6 \%$ of eosinophil percentage.

\section{DISCUSSION}

Ascites are manifestations that can arise in various diseases, one of them in EGE. However, since EGE is a very rare case, this diagnosis is rarely unthinkable in patients with ascites complaints. Ascites fluid cytology may help to guide the true diagnosis. In cytology studies of ascitic fluid can be seen whether there is a malignant process, specific and non-specific, transudative and also immunological cases. In this case, EGE diagnosed after ascites fluid cytology examination done and confirmed by histopathologic examination of gastric biopsy.

Kaijser first reported a patient with eosinophilic gastroenteritis in 1937. EGE most commonly involve stomach and small intestines, but it can involve any part of the G.I. tract. It mainly affects children and adults but it can affect any age group ${ }^{2}$. A World Wide Web database for eosinophilic gastrointestinal disorders has been established, and by its report EGE is associated with atopic conditions in $80 \%$ of cases, and with food allergy in $62 \%$ of cases. In addition, $16 \%$ of patients have, or have had, a family member with a similar disorder. Mortality from EGE is very low and usually due to intestinal perforation, but morbidity may be significant: malnutrition and failure to thrive, abdominal pain, gastric dysmotility, dysphagia, nausea, vomiting, intussusception and obstruction may develop ${ }^{3}$.

The etiology and pathogenesis of EGE is not entirely clear. It seems to come about as a result of a complex interplay of environment, genetics and the immune system; an association between EGE, collagenoses, allergy and hypereosinophilic syndrome (HES) has been reported ${ }^{4,5,6}$ Eosinophils are normally present in various tissues at low levels; in the gastrointestinal tract, they are predominantly located in the lamina propria of the mucosa, but not in the Peyer's patches. However, these areas become infiltrated with eosinophils in EGE. The role of the eosinophils in the gastrointestinal tract is primarily limited to their role in innate anti-parasite immunity, which brings about a regulatory influence on the function of other lymphocytes, participation in antigen presentation, and, possibly, tumor surveillance. The exact reasons why eosinophils accumulate in the gastrointestinal mucosa are not clear, but their degranulation leads to a severe inflammatory response in the mucosa via reactive oxygen species formation, eosinophil derived neurotoxins, and halide acids. Substances found in eosinophilic granules, major basic protein (MBP) I and II as well as eosinophil cationic protein (ECP) accumulate in the extracellular spaces of intestinal tissue of the patients with EGE, as demonstrated by biopsies? ${ }^{7}$.

Eosinophilic gastroenteritis is classified according to the predominance of eosinophilic infiltration in the different layers of the intestinal wall (Klein classification): mucosal, muscularis and serosal forms. Clinical manifestations depend on the affected layers and range from barely perceptible symptoms to intestinal obstruction or ascites. The most common mucosal form of EGE manifests with abdominal pain, nausea, vomiting, diarrhea, sometimes with hematochezia, and protein losing enteropathy, which may lead to weight loss and malnutrition. Muscularis involvement results in gut wall thickening and may lead to obstruction. The serosal form is the most unusual, and leads to EA, as suspected in this case. In serosal form, mucosal biopsies may contain no eosino-phils, since the serosal layer is predominantly involved ${ }^{8}$.

There is no single diagnostic test or procedure that would point directly to the diagnosis of EGE, and there are no strict or uniform diagnostic criteria for it. When it is suspected on the basis of clinical presentation or the re- sults of tissue biopsy, other causes of hypereosinophilia, such as drug reaction, malignancy, parasites, infection or systemic disease should first be excluded. Diagnostic evaluation of the patient with suspected EGE should include complete blood cell count and differential, erythrocyte sedimentation rate, $\mathrm{C}$ reactive protein, amylase, stool studies for ova and parasites, upper and lower gastrointestinal endoscopy with biopsies, bone marrow biopsy, allergen studies (skin testing and RASTs), and IgE and IL-5 levels. For ascites, paracentesis should be performed, and the ascitic fluid should be sent for cytology, cell count and differential, Gram 
stain, culture, including culture for tuberculosis, glucose, protein, albumin, lactate dehydrogenase, IL5 , and IgE levels ${ }^{9}$.

Parasitic infestation with Strongiloides and Toxocara may present with symptoms of gastroenteritis and EA, and they need to be excluded prior to making the diagnosis of $\mathrm{EGE}^{10,11}$. Of note, detection of a parasitic infestation especially with Strongiloides is important, since initiation of steroid therapy in patients with this condition may lead to disseminated infection and death. Serum Ig-E elevation may point to occult parasitic infestation or an atopic variant of $\mathrm{EGE}^{7}$.

Endoscopic evaluation may demonstrate changes in the gastrointestinal mucosa varying from near-normal appearance to severe inflammation, with erosions, exudates, furrowing, polyps, mucosal rings, and stricture formation ${ }^{12}$. Biopsies demonstrate eosinophilrich inflammation, sometimes with extracellular eosinophilic granules, containing both MBP and ECP, which can be detected immunohistochemically ${ }^{7}$. Abdominal ultrasound and computer tomography may demonstrate intestinal wall thickening, ascites, pleural effusions, and hepatosplenomegaly in patients with $\mathrm{EGE}^{13}$.

The diagnosis of EA might be difficult to make, since it is more common in the serosal form of EGE in which systemic eosinophilia might be absent and there may be no eosinophilic infiltration of the gastrointestinal mucosa. Although laparoscopic serosal biopsies may be required for a definitive diagnosis, ascitic fluid eosinophilia and a dramatic response to treatment with steroids indirectly confirm the diagnosis of EGE and EA, as was observed in this patient ${ }^{14}$.

In summary, EGE is a rare entity and it should be kept in mind in patients of unexplained ascites. Absence of malignancy, presence of ascitic fluid eosinophilia and a dramatic response to treatment with steroids confirm in-directly the diagnosis of EGE and EA, as was observed in this patient.

\section{REFERENCES}

1. Zhou HB, Chen JM, Du Q. Eosinophilic gastroenteritis with as-cites and hepatic dysfunction. World J Gastroenterol. 2007; 13:
1303-1305.

2. Kaijser R. Allergic disease of the gut from the point of view from the surgeon. Arch Klin Chir 1937; 188: 36-64.

3. Guajardo JR, Plotnick LM, Fende JM, Collins MH, Putnam PE, Rothenberg ME. Eosinophilassociated gastrointestinal disorders: a worldwide-web based registry. J sPediatr 2002; 141: 576-581.

4. Vanderhoof JA, Young RJ. Allergic disorders of the gastroin- testinal tract. Curr Opin Clin Nutr Metab Care 2001; 4: 553-556

5. Sunkureddi PR, Luu N, Xiao SY, Tang WW, Baethge BA. Eosinophilic enteritis with systemic lupus erythematosus. South Med J 2005; 98: 1049-1052.

6. Rimbrot S, Bennett M, Komorovski M, Levy Y. Eosinophilic ascites as a presenting symptom of the hypereosinophilic syndrome. Harefuah 2001; 140: 471-472, 567.

7. Rothenberg ME. Eosinophilic gastrointestinal disorders (EGID). J Allergy Clin Immunol 2004; 113: 11-28.

8. Talley N, Shorter R, Phillips S, Zinsmeister A. "Eosinophilic gastroenteritis: a clinicopathological study of patients with disease of the mucosa, muscle layer, and subserosal tissues". Gut 1990;31:54-58.

9. Hepburn IS, Sridhar S, Schade RR. Eosinophilic ascites, an unu-sual presentation of eosinophilic gastroenteritis: A case report and review. World J Gastrointest Pathophysiol. 2010; 1: 166-170.

10. Chira O, Badea R, Dumitrascu D, Serban A, Branda H, al Hajjar N, Chiorean E, Cruciat C. Eosinophilic ascites in a patient with toxocara canis infection. A case report. Rom $J$ Gastroenterol 2005; 14: 397-400.

11. Lawate P, Singh SP. Eosinophilic ascites due to Strongyloides stercoralis. Trop Gastroenterol 2005; 26: 91-92.

12.Fox VL. Eosinophilic esophagitis: endoscopic findings. Gas- trointest Endosc Clin N Am 2008; 18: 45-57. 
13.Lee CM, Changchien CS, Chen PC, Lin DY, Sheen IS, Wang CS, Tai DI, Sheen-Chen SM, Chen WJ, Wu CS. Eosinophilic gastroenteritis: 10 years experience. Am J Gastroenterol 1993; 88: 70-74.
14. To Y, Ogawa C, Otomo M, Arai Y, Sano Y, Tashiro Y, Furuta K, Wakabayashi K, Ito K. A case of eosinophilic gastroenteritis complicated with ileus and ascites collection. Arerugi 1999; 48: 50-55. 